\title{
Eleventh Amendment and Other Sovereign Immunity Doctrines: Part One
}

\section{Citation}

Martha A. Field, Eleventh Amendment and Other Sovereign Immunity Doctrines: Part One, 126 U. Pa. L. Rev. 515 (1978).

\section{Published Version}

http://scholarship.law.upenn.edu/penn_law_review/vol126/iss3/2/

\section{Permanent link}

http://nrs.harvard.edu/urn-3:HUL.InstRepos:12967872

\section{Terms of Use}

This article was downloaded from Harvard University's DASH repository, and is made available under the terms and conditions applicable to Other Posted Material, as set forth at http:// nrs.harvard.edu/urn-3:HUL.InstRepos:dash.current.terms-of-use\#LAA

\section{Share Your Story}

The Harvard community has made this article openly available.

Please share how this access benefits you. Submit a story.

Accessibility 


\title{
THE ELEVENTH AMENDMENT AND OTHER SOVEREIGN IMMUNITY DOCTRINES: PART ONE
}

\author{
Martha A. Fueld $\dagger$
}

This article is the first of a series collectively entitled The Eleventh Amendment and Other Sovereign Immunity Doctrines. The present article introduces the issues to be addressed by the series, and suggests that sovereign immunity is a common law doctrine, and is not constitutionally compelled. The second article will address congressional power to override state immunity. The third article will discuss questions respecting the relief available from state defendants.

\section{AN Overview}

The one interpretation of the eleventh amendment to which everyone subscribes is that it was intended to overturn Ghisholm $v$. Georgia. ${ }^{1}$ Chisholm was a case in the Supreme Court's original jurisdiction in which South Carolina citizens sued the State of Georgia to recover on confiscated bonds. Rejecting the objection that it lacked jurisdiction over private individuals' suits against a state, the Court entered a default judgment against Georgia, which had declined to appear.

There is no agreement whether Chisholm was "right" or "wrong" in the sense of according with the intent of the Constitution's Framers. The conventional view ${ }^{2}$ is that the Supreme Court departed from the Framers' intent that states be immune from private suits, and that the eleventh amendment restored the original understanding. Recent studies have eroded that theory, however, by pointing out statements contemporary with the adoption of the

$\dagger$ Professor of Law, University of Pennsylvania. A.B. 1965, Radcliffe College; J.D. 1968, University of Chicago. Member, District of Columbia Bar.

This Article was written pursuant to a fellowship from the Research Institute on Legal Assistance. () Copyright 1977 by National Legal Services Corporation.

12 U.S. (2 Dall.) 419 (1793).

2 E.g., Monaco v. Mississippi, 292 U.S. 313, 325 (1934); Hans v. Louisiana, 134 U.S. 1, 12 (1890); M. IrISh \& J. Prothro, The Polmtrcs of AMarrican Democracy 117 (3d ed. 1965); C. Leedham, Our Changing Constitution 51 (1964); 1 C. Warren, The Supreme Court in Untted States Fistory 91, 96 (1922); Cullison, Interpretation of the Eleventh Amendment (A Case of the White Knight's Green Whiskers), 5 Hous. L. Rev. 1, 7, 9 (1967). 
Constitution indicating that states might be subject to suit by private individuals. ${ }^{3}$

There is also little agreement about many issues concerning the scope of state sovereign immunity. A few examples: Where, in the Constitution, does sovereign immunity come from? What forms of relief can litigants obtain from the state? How is it determined whether a suit is against the state or against an official as an individual? Can Congress, legislating under article I, lift a state's immunity from suit in federal court without the state's consent? Can Congress, legislating under article I, remove a state's immunity from suit in state court, without the state's consent?

One might expect that a look at the language of the eleventh amendment would help resolve most sovereign immunity issues. The problem is that the eleventh amendment is universally taken not to mean what it says. It states: "[ $t]$ he Judicial power of the United States shall not be construed to extend to any suit in law or equity, commenced or prosecuted against one of the United States by Citizens of another State, or by Citizens or Subjects of any Foreign State." While this language quite clearly includes only actions brought "by Citizens of another State" or foreign citizens or subjects (noncitizen suits), the amendment has long been held to protect states from suits by its own citizens (citizen suits), ${ }^{4}$ by federal corporations, ${ }^{5}$ and by foreign states. ${ }^{6}$ Moreover, the amendment, contrary to its language, has been held to apply to suits in admiralty as well as to those in law and equity. ${ }^{7}$ And although the amendment denies to the federal courts "the judicial power" to hear the described cases, it has consistently been accepted that the forbidden cases could be brought in federal court upon the state's consent. ${ }^{8}$

3 E.g., C. Jacobs, The Eleventr AMENDMENT and Sovereign IMMunity (1972); Nowak, The Scope of Congressional Power to Create Causes of Action Against State Governments and the History of the Eleventh and Fourteenth Amendments, 75 Corom. L. REv. 1413 (1975). The first Justice Harlan also believed, as early as 1890, that Chisholm "was based upon a sound interpretation of the Constitution as that instrument then was." Hans v. Louisiana, 134 U.S. 1, 21 (1890) (concurring opinion). The Court's opinion in New Hampshire v. Louisiana, 180 U.S. 76, 91 (1883), seemingly also supports the correctness of Chisholm.

4 The leading case is Hans v. Louisiana, 134 U.S. 1 (1890). See Duhne v. New Jersey, 251 U.S. 311, 313 (1920); Fitts v. McGhee, 172 U.S. 516, 524-25 (1899); North Carolina v. Temple, 134 U.S. 22 (1890).

5 Smith v. Reeves, 178 U.S. $436,445-49$ (1900).

6 Monaco v. Mississippi, 292 U.S. 313 (1934).

7 Ex parte New York, 256 U.S. 490, 497-500 (1921).

s Clark v. Barnard, 108 U.S. 436, 447 (1883), is the "leading case" on this issue although the state in that case, as a voluntary intervenor to obtain money that had been paid into the court, may have been more in the role of a plaintiff than a defendant. But the rule that jurisdiction attaches upon consent to suit has been followed when the state was clearly in the posture of defendant. Parden v. 
Actually, there is some dispute whether the "extensions" of the eleventh amendment-most notably the extension to suits by a state's own citizens-are compelled by that amendment itself or instead have another source. What that source might be is also a question of dispute, the implications of which we will explore herein. It has long been held, at any rate, that the doctrine limiting suits by a state's own citizens is of constitutional dimension. ${ }^{9}$ It may not be of great consequence whether this constitutional rule follows from the eleventh amendment or instead from another source, as becomes apparent when one reflects upon the similarity of doctrines of the federal government's immunity. Federal immunity clearly does not derive from the eleventh amendment, although it has no other apparent constitutional source. ${ }^{10}$ Yet in substance it has developed as an almost exact counterpart of eleventh amendment-state sovereign immunity doctrines. ${ }^{11}$ (In fact, the theory behind the doctrines of state and federal sovereign immunity is sufficiently similar that the reasoning of cases discussing federal sovereign immunity almost always carries over to eleventh amendment

Terminal Ry., 377 U.S. 184 (1964); Petty v. Tennessee-Missouri Bridge Comm'n, 359 U.S. 275 (1959). Accord, Kennecott Copper Corp. v. State Tax Comm'n, 327 U.S. 573, 577 (1946) (rule stated but no consent found); Ford Motor Co. v. Dep't of Treasury, 323 U.S. 459, 464-65 (1945); Missouri v. Fiske, 290 U.S. 18, 24 (1933); Hans v. Louisiana, 134 U.S. 1, 17 (1890). Cf. United States v. Louisiana, 123 U.S. 32 (1887) (upon United States' consent to suit, action against it falls within "the judicial power").

Recently, Justice Brennan has raised objections to this view, and he claims that whether federal courts have jurisdiction over noncitizen suits, upon the state's consent, should be deemed an open question. Employees of Dep't of Public Health and Welfare v. Department of Public Health and Welfare, 411 U.S. 279, 298, 310, 321-22 (1973) (Government Employees) (dissenting opinion). For a possible solution to the consent dilemma, see text accompanying notes 95-97 infra.

In other respects, however, the concept of sovereign immunity as a jurisdictional limitation has been preserved; for example, the sovereign immunity defense is not lost by a failure to raise it in the lower federal courts at trial. Edelman v. Jordan, 415 U.S. 651, 677-78 (1974). But see Vecchione v. Wohlgemuth, 558 F.2d 150 (3d Cir. 1977), cert. denied, 46 U.S.L.W. 3303 (U.S. Nov. 8, 1977) (No. 77-382).

9 Employees of Dep't of Public Health and Welfare v. Department of Public Health and Welfare, 411 U.S. 279, 285 (1973); Ford Motor Co. v. Dep't of Treasury, 323 U.S. 459, 464 (1945); Ex parte Young, 209 U.S. 123, 150 (1908); Chandler v. Dix, 194 U.S. 590, 591 (1904). Nevertheless, the first case sustaining a state's claim of immunity from federal suits brought by citizens did not ground that immunity in the Constitution. See notes 80-81 infra \& accompanying text (discussing Hans v. Louisiana, 134 U.S. I (1890)).

10 The doctrine may not even be constitutionally required. See United States v. Lee, 106 U.S. 196, 205-07 (1882); Cohens v. Virginia, 19 U.S. (6 Wheat.) 264, 411-12 (1821).

11 For the principal difference, see note 24 infra. 
cases (and other state sovereign immunity cases) and vice versa. ${ }^{12}$ Accordingly, quite a few cases dealing with the immunity of the federal government are prominent in this Article, despite Congress' recent abrogation of the sovereign immunity of the United States; ${ }^{13}$ they are useful in piecing together the Court's general theory of sovereign immunity, which today is limited primarily to suits against state governments and state officials.) Whether all suits recognizing state sovereign immunity are deemed within the eleventh amendment's protection or not will be of little consequence as long as the sovereign immunity protection outside of the eleventh amendment continues to be so remarkably like the protection the amendment affords.

While the foregoing judicial interpretations of the reach of sovereign immunity are difficult to justify in terms of clearcut constitutional language, at least it is, and has long been, clear what those rules are. ${ }^{14}$ Other sovereign immunity issues have been much more difficult to resolve. One might imagine it to be self-evident, given the foregoing, that when a private individual, for example, brings a suit against a state, sovereign immunity applies. But how is one to tell whether the suit is against the state? Simply by whether the state is named as the defendant? Chief Justice Marshall announced that rule in Osborn v. Bank of the United States, ${ }^{15}$

12 See Cunningham v. Macon \& B.R.R., 109 U.S. 446, 451 (1883); United States v. Lee, 106 U.S. 196, 206-07 (1882). See also Monaco v. Mississippi, 292 U.S. 313 (1934); Ex parte New York, 256 U.S. 490, 497 (1921). Perhaps the reason for the similarity of rules is that the dispositive question, for both states' and United States' immunity, is conceptualized as whether the suit is against the government; the complex of sovereign immunity rules, for both states and the United States, is a way of arriving at an answer to this question.

13 Pub. L. No. 94-574, $\S 1,90$ Stat. 2721 (amending 5 U.S.C. $\$ \S 702,703$ (1976)). That enactment provides principally that "[a]n action in a court of the United States seeking relief other than money damages and stating a claim that an agency or an officer or employee thereof acted or failed to act in an official capacity or under color of legal authority shall not be dismissed nor relief therein denied on the ground that it is against the United States or that the United States is an indispensable party. The United States may be named as a defendant in any such action, and a judgment or decree may be entered against the United States. . .."

Damage claims against the United States can be prosecuted under the Tucker Act, 28 U.S.C. $\$ \$ 1346,1491$ (1970), and the Federal Tort Claims Act, 28 U.S.C. $\$ 1346$ (b) (1970). Those provisions are not affected by the recent enactment.

14 There are, of course, dissents. See, for example, Justice Brennan's opinion in Government Employees adopting positions quite different from the majority's views on suits between a state and its own citizens, and on the effect of state consent to suit. 411 U.S. at 298. See also Edelman v. Jordan, 415 U.S. 651, 687-88 (1974) (Brennan, J., dissenting).

1522 U.S. (9 Wheat.) $738,846,857$ (1824). Osborn was the auditor of the State of Ohio. The Court did not treat the case as one brought by the United States; rather, it treated the Bank as a private plaintiff. (Similarly, the Court held during this period that state government corporations do not partake of the state's immunity. Briscoe v. Bank of Kentucky, 36 U.S. (1I Pet.) 257 (1837); Bank of 
but it was not followed as early as Governor of Georgia v. Madrazo,16 the Court, again speaking through Chief Justice Marshall, saying that "where the chief magistrate of a state is sued, not by his name, but by his style of office, and the claim made upon him is entirely in his official character, we think the state itself may be considered as a party on the record." 17 One could, I suppose, have the rule that a suit is against the state whenever the state is named as defendant or whenever the defendant is a public official acting in his or her official capacity. (The litigation then would concern the correct line between acting in an official and a private capacity.) This country departed from that rule at least as early as 1882 when the Court held in United States $v$. Lee ${ }^{18}$ that suits to recover one's own property from the government are not suits against the sovereign. ${ }^{19}$ Ex parte Young ${ }^{20}$ placed another limitation upon the principle that a suit is against the state whenever the state or a public official, acting in his or her official capacity, is the named defendant. The Court there held that suits to enjoin unconstitutional state action may be maintained against public officials.

There is therefore an opening for maintaining suit against the state, available even to the parties explicitly denied the ability to sue by the Constitution. Those parties are not able to sue when the state is named as defendant, but they are sometimes allowed to sue when a public official is named instead. ${ }^{21}$ In 1949, in Larson $v$.

Kentucky v. Wister, 27 U.S. (2 Pet.) 318 (1829); Bank of United States v. Planters' Bank, 22 U.S. (9 Wheat.) 904 (1824).)

1026 U.S. ( 1 Pet.) 110 (1828). The plaintiff in that case sought to recover slaves, currently in the state government's possession. The slaves had been seized from him under the authority of the governor, on the ground that they had been illegally brought into the state. The plaintiff also sought money from the state treasury representing the proceeds from those of the slaves who had already been resold.

1726 U.S. ( 1 Pet.) at 123. In fact the Osborn rule was not definitively repudiated until much later, in In re Ayers, 123 U.S. 443 (1887) and Pennoyer v. McConnaughy, 140 U.S. 1 (1891). In the interim, other cases adhered to the Osborn rule. Board of Liquidation v. McComb, 92 U.S. 531 (1876); Davis v. Gray, 83 U.S. (16 Wall.) 203 (1872).

18106 U.S. 196 (1882). See note 12 supra \& accompanying text.

19 Osborn v. Bank of the United States, 22 U.S. (9 Wheat.) 738 (1824), may be deemed to have established the rule much earlier. See also Meigs v. M'Clung's Lessee, 13 U.S. (9 Cranch) 11 (1815); United States v. Peters, 9 U.S. (9 Cranch) 115 (1809).

For a later limitation on the rule that one can recover one's own property, see note 26 infra \& accompanying text.

20209 U.S. 123 (1908). For earlier cases foreshadowing the rule, see, e.g., Smyth v. Ames, 169 U.S. 466 (1898); Allen v. Baltimore \& O.R.R., 114 U.S. 311 (1885); Davis v. Gray, 83 U.S. (16 Wall.) 203 (1872).

21 The case name, United States v. Lee, suggests the suit was against the government itself rather than its officers. In fact, the circuit court had dismissed the suit against the United States, at the request of the plaintiffs, and against all 
Domestic \& Foreign Commerce Corp.,22 the Court described this opening and attempted to delineate the suits against public officers that would be allowed. It said that in damage actions the question was easy: the suit is against the named state official. In suits for specific relief the question is more difficult, according to the Court. ${ }^{23}$ The answer it provided is that officials may be sued for unconstitutional action or action contrary to statute ${ }^{24}$ but not for actions that are "merely illegal" in the sense of being tortious or in breach of

other defendants except Frederick Kaufman and Richard P. Strong, in whose names the Attorney General of the United States was acting. Judgment was rendered against those individuals in the circuit court, ejecting them from the disputed land, a judgment that the Supreme Court affirmed. 106 U.S. 196 (1882).

22337 U.S. 682 (1949).

23 The Court's language setting out this structure for analyzing relief problems bears reading:

The crucial question is whether the relief sought in a suit nominally addressed to the officer is relief against the sovereign. In a suit against the officer to recover damages for the agent's personal actions, that question is easily answered. The judgment sought will not require action by the sovereign or disturb the sovereign's property. There is, therefore, no jurisdictional difficulty. The question becomes difficult and the area of controversy is entered when the suit is not one for damages but for specific relief: i.e., the recovery of specific property or monies, ejectment from land, or injunction either directing or restraining the defendant officer's actions. ... [T] his question .... arises whenever suit is brought against an officer of the sovereign in which the relief sought from him is not compensation for an alleged wrong but, rather, the prevention or discontinuance, in rem, of the wrong.

Id. 687-88 (footnotes omitted).

24 Larson's rule of official accountability for statutory (as distinct from constitutional) violations does not, however, of its own force, apply to actions against state officials. Although in most respects the states' and the United States' sovereign immunity doctrines are counterparts, see text accompanying notes 12-13 supra, the rules on official accountability for statutory violations may differ, because federal law will not impose the rules of accountability when the cause of action is statecreated. Federal officials are accountable, then, for unconstitutional action or action contrary to statute, but state officers' defenses of sovereign immunity will fail, as a matter of federal law, only in suits with a federal constitutional basis (including, through the Supremacy Clause, suits alleging breach of federal legislation). State law doctrines of sovereign immunity will be followed when the basis of a lawsuit is a violation of state law-whether statutory or common law. Gerr v. Emrick, 283 F.2d 293 (3d Cir. 1960); Zeidner v. Wulforst, 197 F. Supp. 23, 25 (E.D.N.Y. 1961). See also Broward County v. Wickman, 195 F.2d 614 (5th Cir. 1952). Whether a suit against a state officer alleging breach of a state statute is considered actionable or is instead deemed a suit against the sovereign is therefore a matter of state law.

Prior to Erie R.R. v. Tompkins, 304 U.S. 62 (1938), however, state officials acting outside their statutory authority, and even officials acting tortiously or in negligent disregard of state laws, were deemed to be acting as individuals and were personally liable. Martin v. Lankford, 245 U.S. 547 (1918); Johnson v. Lankford, 245 U.S. 541 ( 1918 ); Louisville \& N.R.R. v. Greene, 244 U.S. 522 (1917); Greene v. Louisville \& Interurban R.R., 244 U.S. 499 (1917); Atchison, T. \& S.F. Ry. v. O'Connor, 223 U.S. 280 (1912); Scully v. Bird, 209 U.S. 481 (1908); Tindal v. Wesley, 167 U.S. 204 (1897); South Carolina v. Wesley, 155 U.S. 542 (1895); Pennoyer v. McConnaughy, 140 U.S. I (1891). 
contract. ${ }^{25}$ This exclusion of tort and contract suits is the principal holding of Larson. ${ }^{26}$ In a footnote, however, the Larson Court added that even a suit based upon unconstitutional conduct or conduct contrary to statute may be precluded "if the relief requested cannot be granted by merely ordering the cessation of the conduct complained of but will require affirmative action by the sovereign or the disposition of unquestionably sovereign property." 27 The effect of this footnote was not wholly evident. Suits requiring affirmative action by the sovereign had been entertained previously, ${ }^{28}$ and they were not mentioned in Larson.

Larson's framework for approaching sovereign immunity issues remains useful today. Its differentiation, for sovereign immunity purposes, between damage actions and those for specific relief has antecedents dating back to the nineteenth century, and the distinction persists as an important element in current sovereign immunity law. The problem area of affirmative action that Larson pinpointed is still a problem area today; the state of the law on that subject remains ill-defined. The major issue in suits for specific relief against public officials remains, however, this question of which forms of relief are permissible.

There have been changes since Larson, however. First, the problem in damage actions has not proved as simple as the Larson Court supposed. Moreover, the recent abrogation of the United States' immunity ${ }^{29}$ has rendered largely irrelevant the distinction that Larson advanced between suits for merely illegal actions and those alleging unconstitutionality or a statutory violation..$^{30}$ Finally, new ways of avoiding the impact of the sovereign immunity doctrines have emerged since Larson. The two most notable are the doctrine of constructive waiver of sovereign immunity and congressional imposition of remedies against the states.

25 Suits against public officials can also be maintained, obviously, if the officials acted in a purely personal capacity. The Court used as an example a suit against a public official concerning a contract for the sale of his personal home. 337 U.S. at 689 .

26 This ruling was new to Larson, despite that Court's laboring to ground it in precedent; the holding in United States v. Lee, 106 U.S. 196 (1882), that one can recover one's property wrongfully held by the state retains its vitality only for suits based on constitutional or statutory violations.

27337 U.S. at 691 n.II (citation omitted).

28 E.g., mandamus actions. See Wilbur v. United States ex rel. Krushnic, 280 U.S. 306 (1930); Houston v. Ormes, 252 U.S. 469 (1920); Lane v. Hoglund, 244 U.S. 174 (1917); Roberts v. United States, 176 U.S. 221 (1900). See generally Work v. United States ex rel. Rives, 267 U.S. 175, 177-78, 184 (1925).

29 See note 13 supra.

30 That distinction already did not affect state sovereign immunity suits. See note 24 supra. 


\section{SOME UnderLying Issues of Constitutional Interpretation}

There are several live disputes concerning eleventh amendment interpretation that seem largely theoretical yet have potential practical significance. In some instances, they also provide some rationale for the enormous difference between the actual scope of sovereign immunity and the language of the eleventh amendment.

\section{A. The Sources of Sovereign Immunity}

\section{Some Possibilities}

The principal issue is what source, other than the eleventh amendment, gives rise to sovereign immunity. Some statements seem to adopt the somewhat bold position that all state sovereign immunity derives from the eleventh amendment, ${ }^{31}$ despite the amendment's wording indicating its applicability only to suits "commenced or prosecuted against one of the United States by Citizens of another State". The apparent rationale is that whatever reasoning requires immunity for noncitizen suits applies equally to suits by a state's own citizens. ${ }^{32}$ Moreover, the Court has reasoned, the eleventh amendment would not have been adopted had it contained a proviso allowing suit by a state's own citizens. ${ }^{33}$ Reasoning thus, opinions occasionally state bluntly that the only proper way to effectuate the eleventh amendment is to disregard its express wording. ${ }^{34}$ This position that the eleventh amendment alone supports

31 E.g., Edelman v. Jordan, 415 U.S. 651, 663 (1974) ("the Hans line of cases permitted the State to raise the Eleventh Amendment as a defense to suit by its own citizens"); United States v. Mississippi, 380 U.S. 128, 140 (1965); Ford Motor Co. v. Dep't of Treasury, 323 U.S. 459, 464 (1945); Ex parte Young, 209 U.S. 123, 150 (1908); McAuliffe v. Carlson, 520 F.2d 1305, 1307 n.4 (2d Cir. 1975), cert. denied, 427 U.S. 911 (1976); Mobil Oil Corp. v. Kelley, 493 F.2d 784, 786 (5th Cir.), cert. denied, 419 U.S. 1022 (1974); Rothstein v. Wyman, 467 F.2d 226, 236-38 \& n.5 (2d Cir. 1972), cert. denied, 411 U.S. 921 (1973).

32 In Hans v. Louisiana the Court said it would be an "anomalous result" to allow suit in the one category of cases and not in the other. It thought such a result would be "startling and unexpected." 134 U.S. at 10-11.

33 Suppose that Congress, when proposing the Eleventh Amendment, had appended to it a proviso that nothing therein contained should prevent a State from being sued by its own citizens in cases arising under the Constitution or laws of the United States: can we imagine that it would have been adopted by the States? The supposition that it would is almost an absurdity on its face.

Hans v. Louisiana, 134 U.S. 1, 15 (1890).

34 Moreover, the Eleventh Amendment is not intended as a mere formula of words, to be slurred over by subtle methods of interpretation, so as to give it a literal compliance, without regarding its substantial meaning and purpose. It is a grave and solemn condition, exacted by sovereign States, for the purpose of preserving and vindicating their sovereign right to deal with their creditors and others propounding claims against them, according 
states' sovereign immunity leaves unexplained the source of the sovereign immunity of the federal government.

Another theory maintains that Chisholm v. Georgia was wrong and that the purpose of the eleventh amendment was to reverse entirely the Court's misconceptions in Chisholm and return to the situation mandated by the Constitution itself: ${ }^{35}$ a situation of full sovereign immunity for state governments, as well as the federal government (whose sovereign immunity Chisholm left unimpaired $\left.{ }^{36}\right)$. This position, though nominally one of reliance on the eleventh amendment, is much like other theories finding sovereign immunity in the Constitution as it was adopted in 1787.

Where does the original Constitution provide for this sovereign immunity? The language usually discussed in this connection is that concerning the extent of "the judicial power" in article III."37 The argument is that the United States' judicial power does not extend to these suits against the state or federal governments. As Justice Marshall explained in Employees of the Department of

to their own views of what may be required by public faith and the necessities of the body politic. We have no right, if we were disposed, to fritter away the substance of this solemn stipulation by any neat and skillful manipulation of its words. We are bound to give it its full and substantial meaning and effect. It is only thus that all public instruments should be construed.

Virginia Coupon Cases, I14 U.S. 269, 332 (dissenting opinion). But see id. 337-38.

35 Ex parte New York, 256 U.S. 490 (1921), may exemplify this position. It speaks of state immunity as a "fundamental rule of which the [Eleventh] Amendment is but an exemplification." Id. 497. On the next page, however, the Court talks as though the eleventh amendment, standing alone, supports all state sovereign immunity rules. Id. 498. The Court's view of the precise source of immunity is thus somewhat confused.

A case that declines precisely to locate the immunity saying simply that "the whole sum of the judicial power granted by the Constitution of the United States does not embrace the authority to entertain a suit brought by a citizen against his own state without its consent" is Duhne v. New Jersey, 251 U.S. 311, 313 (1920).

30 Chisholm v. Georgia, 2 U.S. (2 Dall.) 419, 424 (1793) (argument of Randolph, for plaintiff, conceding United States' immunity); id. 430 (Iredell, J., dissenting); id. 469 (opinion of Cushing, J.); id. 478 (opinion of Jay, C.J.). See also Monaco v. Mississippi, 292 U.S. 313, 321 (1934).

37 The judicial Power shall extend to all Cases, in Law and Equity, arising under this Constitution, the Laws of the United States, and Treaties made, or which shall be made, under their Authority;-to all Cases affecting Ambassadors, other public Ministers and Consuls; - to all Cases of admiralty and maritime Jurisdiction;-to Controversies to which the United States shall be a Party;-to Controversies between two or more States;-between a State and Citizens of another State;-between Citizens of different States;-between Citizens of the same State claiming Lands under Grants of different States, and between a State, or the Citizens thereof, and foreign States, Citizens or Subjects.

U.S. Const. art. III, $\$ 2$. 
Public Health and Welfare v. Department of Public Health and Welfare (Government Employees): ${ }^{38}$

The root of the constitutional impediment to the exercise of the federal judicial power in a case such as this is not the Eleventh Amendment but Art. III of our Constitution. Following the decision in Chisholm v. Georgia, 2 Dall. 419 (1793), in which this Court held that federal jurisdiction encompassed a suit brought against a nonconsenting State by citizens of another State, the Eleventh Amendment was introduced to clarify the intent of the Framers concerning the reach of the federal judicial power. See, e.g., Hans v. Louisiana, 134 U.S., at 11-14. It had been widely understood prior to ratification of the Constitution that the provision in Art. III, § 2, concerning "Controversies . . . between a State and Citizens of another State" would not provide a mechanism for making States unwilling defendants in federal court. The Court in Chisholm, however, considered the plain meaning of the constitutional provision to be controlling. The Eleventh Amendment served effectively to reverse the particular holding in Chisholm, and, more generally, to restore the original understanding, see, e.g., Hans v. Louisiana, [134 U.S.] at 11-15. Thus, despite the narrowness of the language of the Amendment, its spirit has consistently guided this Court in interpreting the reach of the federal judicial power generally, and "it has become established by repeated decisions of this court that the entire judicial power granted by the Constitution does not embrace authority to entertain a suit brought by private parties against a State without consent given: not one brought by citizens of another State, or by citizens or subjects of a foreign State, because of the Eleventh Amendment; and not even one brought by its own citizens, because of the fundamental rule of which the Amendment is but an exemplification," Ex parte New York, No. 1, 256 U.S. 490, 497 (1921); see Smith v. Reeves, 178 U.S. 436, 447-449 (1900).

One problem with this reasoning is that all agree that states may be sued in federal courts with their consent-that once they

38411 U.S. 279, 291-92 (1973) (concurring opinion) (footnotes omitted). Other statements indicating that states' immunity, in citizen suits, derives directly from article III are: Virginia Coupon Cases, 114 U.S. 269, 337-38 (1885) (Bradley, J., dissenting); Miller, Service of Process on State, Local and Foreign Governments Under Rule 4, Federal Rules of Civil Procedure-Some Unfinished Business for the Rulemakers, 46 F.R.D. 101, 108-09 \& n.22 (1969). See also Ex parte New York, 256 U.S. 490,497 (1921), discussed note 35 supra. 
consent, the "judicial power of the United States" does extend to this category of suit. This does not fit easily with the theory that the suits are otherwise outside the "judicial power"; in other instances limitations on federal judicial power are unaffected by the consent of the parties. ${ }^{39}$ Even apart from the theory that article III is the source of immunity, however, the same problem would be encountered under the eleventh amendment. It, too, is phrased as a limitation on judicial power, yet it is established that the bar disappears upon the state's consent to suit. ${ }^{40}$

The other problem with viewing article III as the source of sovereign immunity is that some parties are permitted suits against the state. For example, a state may sue another state, ${ }^{41}$ and the United States may sue a state. ${ }^{42}$ How is one to tell which suits against sovereignties are outside the federal judicial power, and which are not, when nothing in article III's language differentiates between the allowable suits and the forbidden ones?

In Monaco $v$. Mississippi ${ }^{43}$ the Court answered this question, saying that sovereign immunity limits the judicial power where such a limitation is "inherent in the Constitutional plan": ${ }^{44}$

Manifestly, we cannot rest with a mere literal application of the words of $\$ 2$ of Article III [granting the Court jurisdiction of various categories of cases, e.g., cases in which a State shall be party], or assume that the letter of the Eleventh Amendment exhausts the restrictions upon suits against nonconsenting States. Behind the words of the constitutional provisions are postulates which limit and control. ... There is . . The postulate that States of the Union, still possessing attributes of sovereignty, shall be immune from suits, without their consent, save where

3913 C. Wright, A. Miller \& E. Cooper, Federat Practice and Procedore $\$ 3522$, at 46 n.6 (1975 \& Supp. 1977) [hereinafter cited as Wrighr \& MrenER] (citing cases); Louisville \& Nashville R.R. v. Mottley, 211 U.S. 149 (1908).

40 See cases cited note 8 supra.

41 Monaco v. Mississippi, 292 U.S. 313, 328-29 (1934) (dictum); Rhode Island v. Massachusetts, 37 U.S. (I2 Pet.) 657, 729 (1838).

42 United States v. Mississippi, 380 U.S. 128 (1965); Monaco v. Mississippi, 292 U.S. 313,329 (1934) (dictum); United States v. Texas, 143 U.S. 621, 644-45 (1892).

43292 U.S. 313 (1934).

44 Id. 329. See also id. 322-24, 330. The phrase, of course, could include anything. One might find it "inherent in the constitutional plan" that all federal questions be litigable in federal court-or all federal constitutional questions-or all subjects within Congress' power, but the Court has not so held. See Louisiana v. Jumel, 107 U.S. 711 (1883). But see Cohens v. Virginia, 19 U.S. (6 Wheat.) 264, 383, 392, 407 (1821) (Marshall, C.J.). 
there has been "a surrender of this immunity in the plan of the convention." The Federalist, No. 81.45

Apparently, the Court knows whether this immunity was surrendered in the plan of the convention by its own evaluation of the sense of the situation. Entertainment of suits between states "was essential to the peace of the Union"; ${ }^{46}$ accordingly, for such suits, "the States by the adoption of the Constitution, ... . waived their exemption from judicial power." ${ }^{4} \tau$ Similarly, the ability of the United States to sue states is "inherent in the constitutional plan." 48 And a foreign state may not sue an unconsenting state (the decision rendered in Monaco v. Mississippi) because

[c]ontroversies between a State and a foreign State may involve international questions in relation to which the United States has a sovereign prerogative. ... The National Government, by virtue of its control of our foreign relations is entitled to employ the resources of diplomatic negotiations and to effect such an international settlement as may be found appropriate, through treaty, agreement of arbitration, or otherwise. It cannot be supposed that it was the intention that a controversy growing out of the action of a State, which involves a matter of national concern and which is said to affect injuriously the interests of a foreign State, or a dispute arising from conflicting claims of a State of the Union and a foreign state as to territorial boundaries, should be taken out of the sphere of international negotiations and adjustment through a resort by the foreign State to a suit under the provisions of $\$ 2$ of Article III. In such a case, the State has immunity from suit without her consent and the National Government is protected by the provision prohibiting agreements between States and foreign powers in the absence of the consent of Congress. While, in this instance, the proposed suit does not raise a question of national concern, the constitutional provision which is said to confer jurisdiction should be construed in the light of all its applications. ${ }^{49}$

In short, the Court decides on an ad hoc basis which categories of law suits are excluded from immunity, according to its own view whether the exclusion is necessary.

45292 U.S. at 322-23 (footnote omitted).

46 Id. 328.

47 Id.

48 Id. 329.

49 Id. 331-32. 
Article III's language concerning the United States' judicial power is certainly not a very explicit basis on which to rest the doctrine of state sovereign immunity that has evolved. The position nonetheless finding the immunity rests ultimately upon a view of the Framers' intent. There are two basic difficulties with this position, which will be discussed in turn: (1) it is by no means as clear as has been claimed that the Framers did intend states to retain sovereign immunity; and (2) even more basic, proponents of sovereign immunity as a constitutional requirement flowing from article III run together two arguments: the argument that article III does not abrogate states' sovereign immunity is imperceptibly transformed into an argument that article III itself imposes sovereign immunity.

\section{Did the Framers Intend Sovereign Immunity to Survive} Article III?-The Possibility of Article III Abrogation

The accepted position has long been that the Framers intended sovereign immunity to survive the Constitution, as originally adopted. ${ }^{50}$ The evidence generally set forth in support is three statements-by no less a threesome than Madison, Marshall, and Hamilton-that the states were not, under the proposed Constitution, subject to suit without their consent.

Madison's and Marshall's statement were made in 1788 before the Virginia Convention in the ratification debates. Madison stated:

[The Supreme Court's] jurisdiction in controversies between a state and citizens of another state is much objected to, and perhaps without reason. It is not in the power of individuals to call any state into court. The only operation it can have, is that, if a state should wish to bring a suit against a citizen, it must be brought before the federal court. This will give satisfaction to individuals, as it will prevent citizens, on whom a state may have a claim, being dissatisfied with the state courts. ...

But this will not go beyond the cases where they may be parties. A femme covert may be a citizen of another state, but cannot be a party in this court. A subject of a

50 I C. WARREN, supra note 2, at 91, 96. See also cases and authorities cited note 2 supra.

It is clear that sovereign immunity existed at common law in the American Colonies at the time of the Revolution, although the sense of this is open to question. See C. JACOBS, supra note 3, at 150-52; Mathis, The Eleventh Amendment: Adoption and Interpretation, 2 GA. L. Rev. 207, 207-11 (1968). 
foreign power, having a dispute with a citizen of this state, may carry it to the federal court; but an alien enemy cannot bring suit at all. It appears to me that this can have no operation but this-to give a citizen a right to be heard in the federal courts; and if a state should condescend to be a party, this court may take cognizance of it. ${ }^{51}$

On the same day, as part of the same debate, John Marshall declared:

With respect to disputes between $a$ state and the citizens of another state, its jurisdiction has been decried with unusual vehemence. I hope that no gentleman will think that a state will be called at the bar of the federal court. Is there no such case at present? Are there not many cases in which the legislature of Virginia is a party, and yet the state is not sued? It is not rational to suppose that the sovereign power should be dragged before a court. The intent is, to enable states to recover claims of individuals residing in other states. I contend this construction is warranted by the words. But, say they, there will be partiality in it if a state cannot be defendant-if an individual cannot proceed to obtain judgment against a state, though he may be sued by a state. It is necessary to be so, and cannot be avoided. I see a difficulty in making a state defendant, which does not prevent its being plaintiff. If this be only what cannot be avoided, why object to the system on that account? If an individual has a just claim against any particular state, is it to be presumed that, on application to its legislature, he will not obtain satisfaction? But how could a state recover any claim from a citizen of another state, without the establishment of these tribunals? 52

The same year Alexander Hamilton wrote in The Federalist:

Though it may rather be a digression from the immediate subject of this paper, I shall take occasion to mention here a supposition which has excited some alarm upon very mistaken grounds. It has been suggested that an assignment of the public securities of one State to the citizens of another, would enable them to prosecute that State in the federal courts for the amount of those securities; a

513 The Debates in the Several State Conventions on the Adoption of Tre Federal Construution 533 ( $\mathrm{J}$. Elliot ed. 1836) [hereinafter cited as Elutot's Debates].

52 Id. 555-56 (emphasis in original). 
suggestion which the following considerations prove to be without foundation.

It is inherent in the nature of sovereignty not to be amenable to the suit of an individual without its consent. This is the general sense, and the general practice of mankind; and the exemption, as one of the attributes of sovereignty, is now enjoyed by the government of every State in the Union. Unless, therefore, there is a surrender of this immunity in the plan of the convention, it will remain with the States, and the danger intimated must be merely ideal. ... [T] here is no color to pretend that the State governments would, by the adoption of that plan, be divested of the privilege of paying their own debts in their own way, free from every constraint but that which flows from the obligations of good faith. The contracts between a nation and individuals are only binding on the conscience of the sovereign, and have no pretensions to a compulsive force. They confer no right of action, independent of the sovereign will. To what purpose would it be to authorize suits against States for the debts they owe? How could recoveries be enforced? It is evident, it could not be done without waging war against the contracting State; and to ascribe to the federal courts, by mere implication, and in destruction of a pre-existing right of the State governments, a power which would involve such a consequence, would be altogether forced and unwarrantable.53

These statements quite clearly maintain state immunity from suit, but the history is by no means as clear as these statements standing alone would suggest. The conventional view accepting state immunity was established in cases that simply ignored the historical evidence on the other side of the question. ${ }^{54}$ That evidence discloses disagreement concerning the status of states' sovereign immunity among those involved in the ratification process,

53 The Federatist No. 81 (A. Hamilton) 511-12 (B. Wright ed. 1961) (Ist ed. 1788) (emphasis in original).

54 E.g., Monaco v. Mississippi, 292 U.S. 313, 323-25 (1934); Williams v. United States, 289 U.S. 553, 574-77 (1933); Hans v. Louisiana, 134 U.S. 1 (1890). Unlike the other two cases, which do not mention countervailing arguments, Hans says that "the opponents of the Constitution" made some counterarguments, but that Madison, Marshall and Hamilton were correct. Id. 12-14. It also ignores the fact that not all of the Constitution's supporters agreed with Madison, Marshall and Hamilton.

A recent case assembling historical sources but omitting all the evidence disagreeing with Madison, Marshall and Hamilton is Edelman v. Jordan, 415 U.S. 651, $660-62 \& 12.9$ (1974). 
a disagreement that was not resolved when the Constitution was adopted. ${ }^{55}$

The debate at that time centered largely upon the meaning of constitutional phrases conferring jurisdiction upon the federal judiciary: "The judicial power shall extend to . . . controversies ... between a State and Citizens of another State; . . . and between a State, or the Citizens thereof, and foreign States, Citizens, or Subjects." 56 Some persons claimed that, by placing within the federal judicial power disputes between states and private individuals, this language prevented states from claiming immunity from suit and thus affirmatively abrogated state sovereign immunity. Madison's, Marshall's and Hamilton's statements were attempts to refute those claims.

The language conferring jurisdiction "between a state and a citizen or citizens of another state" was first used by the Committee of Detail, ${ }^{67}$ a committee of five members charged by the Constitutional Convention with revision of various resolutions, including some dealing with the jurisdiction of the national judiciary. The Committee proposed that " $[\mathrm{t}]$ he jurisdiction of the Supreme Court shall extend to all cases ... (except such as shall regard territory or jurisdiction) between a State and Citizens of another State... and between a State or the Citizens thereof and foreign States, citizens or subjects" ${ }^{58}$-the language that, when embodied in article III, became subject to a claim that it abrogated the states' immunity. Two of the five members of the Committee of Detail (Edmund Randolph and James Wilson) supported that position in the ratification debates. ${ }^{59}$

No consensus concerning this issue is apparent. The views of. the other three Committee members were not publicly expressed, and there is no record of relevant discussion within the Committee.; There was no discussion concerning the meaning of this passage in the debate at the Constitutional Convention, nor was the subject of sovereign immunity mentioned. The subject was discussed in the ratification conventions, especially in Virginia, New York, and

55 Recent studies discussing this evidence are C. JACOBS, supra note 3, at 27-40; Nowak, supra note 3 , at $1425-30$.

56 U.S. ConsT. art. III, $\$ 2$, A similar provision extends jurisdiction "to Controversies to which the United States shall be a Party." The Supreme Court was also given original jurisdiction of "all Cases... in which a State shall be Party." Id.

57 See 2 Records of the Federal Convention of 1787 at 147 (M. Farrand ed. 1937).

$58 \mathrm{Id} .186$.

59 See text accompanying notes 63-64 infra. 
Pennsylvania. ${ }^{80}$ It is in the Virginia debates that we find the Madison and Marshall assertions that suit is not allowable against the states, as well as many of the assertions that it is. The New York convention recommended an amendment to the Constitution providing that the Constitution should not "be construed to authorize any suit to be brought against any state, in any manner whatever" 11 an amendment that would have been unnecessary if the MadisonMarshall-Hamilton interpretation had been generally accepted. ${ }^{62}$

Indeed, in weight of numbers, the anti-immunity comments clearly prevail. As noted above, Edmund Randolph and James Wilson, who had been members of the Committee of Detail, are on record as thinking that the grant of jurisdiction to cases "between a state and citizens of another state" made states subject to suit by private individuals. At the Pennsylvania Convention, James Wilson lauded the "impartiality" of the Constitution in thus allowing the individual citizen to "stand on a just and equal footing" with the State with which he has a controversy. ${ }^{63}$ Edmund Randolph, speaking at the Virginia Convention, similarly assumed that article III allowed individuals to sue states:

I approve of [the Constitution] . . . because it prohibits tender-laws, secures the widows and orphans, and prevents the states from impairing contracts. I admire that part which forces Virginia to pay her debts. . . . When it obliges us to tread in the path of virtue, when it takes away from the most influential man the power of directing our passions to his own emolument, and of trampling upon justice, I hope to be excused when I say, that, were it more objectionable than it is, I should vote for the Union. ${ }^{64}$

Many who opposed ratification also thought that article III abrogated state immunity. (Indeed, it is in reply to their assertions that Madison's and Marshall's statements were made.) Patrick

60 Letters appearing after Chisholm claimed that in the Massachusetts convention also fears had been expressed that the judiciary article would render states suable generally, but supporters of the Constitution had disclaimed that interpretation of article III. See 1 C. WARREN, supra note 2, at 97 n.1.

612 Exuror's Debates, supra note $5 l$, at 409.

62 A similar amendment was urged in Rhode Island, C. JACOBs, supra note 3, at $39 \&$ n.48. Moreover in Virginia, 3 Euriot's DeBates, supra note 51, at 660-61, and North Carolina, 4 id. 246, amendments were introduced that would have excepted from the federal judicial power cases "where the cause of action shall have originated before the ratification of this Constitution." Id. (quoting from the North Carolina amendment).

632 Elitor's Debates, supra note 51, at 491.

043 Elitor's DeBAtes, supra note 51, at 207. 
Henry, speaking in opposition to the Constitution at the Virginia Convention, said:

It has been sufficiently demonstrated that [the rights of the Union] . . . are not secured. It sounds might prettily to gentlemen, to curse paper money and honestly pay debts. But apply to the situation of America, and you will find there are thousands and thousands of contracts, whereof equity forbids an exact literal performance. Pass that government, and you will be bound hand and foot. There was an immense quantity of depreciated Continental paper money in circulation at the conclusion of the war. This money is in the hands of individuals to this day. The holders of this money may call for the nominal value, if this government be adopted. This state may be compelled to pay her proportion of that currency, pound for pound. Pass this government, and you will be carried to the federal court, (if I understand that paper right,) and you will be compelled to pay shilling for shilling. I doubt on the subject; at least, as a public man, I ought to have doubts. A state may be sued in the federal court, by the paper on your table. It appears to me, then, that the holder of the paper money may require shilling for shilling. If there be any latent remedy to prevent this, $I$ hope it will be discovered. ${ }^{65}$

Later, in reply to Madison, ${ }^{66}$ Henry asserted:

As to controversies between a state and the citizens of another state, [Madison's] construction of it is to me perfectly incomprehensible. He says it will seldom happen that a state has such demands on individuals. There is nothing to warrant such an assertion. But he says that the state may be plaintiff only. If gentlemen pervert the most clear expressions, and the usual meaning of the language of the people, there is an end of all argument. What says the paper? That it shall have cognizance of controversies between a state and citizens of another state, without discriminating between plaintiff and defendant. What says the honorable gentleman? The contrary-that the state can only be plaintiff. When the state is debtor, there is no reciprocity. It seems to me that gentlemen may put what construction they please on it. What is justice to be done to one party, and not to the other? If gentlemen take this liberty now, what will they not do when our rights and 
liberties are in their power? $\mathrm{He}$ said it was necessary to provide a tribunal when the case happened, though it would happen but seldom. The power is necessary, because New York could not, before the war, collect money from Connecticut! The state judiciaries are so degraded that they cannot be trusted. This is a dangerous power which is thus instituted. ${ }^{67}$

Similarly George Mason, speaking in Virginia, said:

"To controversies between a state and the citizens of another state." How will their jurisdiction in this case do? Let gentlemen look at the westward. Claims respecting those lands, every liquidated account, or other claim against this state, will be tried before the federal court. Is not this disgraceful? Is this state to be brought to the bar of justice like a delinquent individual? Is the sovereignty of the state to be arraigned like a culprit, or private offender? Will the states undergo this mortification? I think this power perfectly unnecessary. But let us pursue this subject farther. What is to be done if a judgment be obtained against a state? Will you issue a fieri facias? It would be ludicrous to say that you could put the state's body in jail. How is the judgment, then, to be enforced? A power which cannot be executed ought not to be granted. ${ }^{68}$

And Richard Henry Lee, writing in 1787 as "The Federal Farmer," circulated a series of pamphlets in opposition to the Constitution that were influential in both New York and Virginia. ${ }^{69}$ On states' suability he said:

How far it may be proper to admit a foreigner or the citizen of another state to bring actions against state governments, which have failed in performing so many, promises made during the war is doubtful: How far it may be proper so to humble a state, as to oblige it to answer to an individual in a court of law, is worthy of consideration; the states are now subject to no such actions; and this new jurisdiction will subject the states, and many defendants to actions, and processes, which were not in the contemplation of the parties, when the contract was made; all engagements existing between citizens of different states, citizens and

o7 3 Elutot's Debates, supra note 51, at 543-44.

68 Id. 526-27. See also id. 472.

69 C. JACOBS, supra note 3 , at 36. 
foreigners, states and foreigners; and states and citizens of other states were made the parties contemplating the remedies then existing on the laws of the states ... and the new remedy proposed to be given in the federal courts, can be founded on no principle whatever. ${ }^{70}$

It is true that the statements of Henry, Mason and Lee that the Constitution abrogated the states' immunity were made as criticism, with the aim of opposing ratification of the Constitution. They may have been disingenuous, in order to accomplish their object, just as the statements of Madison, Marshall and Hamilton may have discounted the possibility that article III abrogated immunity, in order to assuage states-rightists' fears. ${ }^{71}$ Randolph and Wilson, however, approved the anti-immunity interpretation and supported the ratification of the Constitution. So did Tench Coxe, who wrote that because of the jurisdictional grant "when a dispute arises between the citizens of any state . . . and ... the government of another, the private citizen will not be obliged to go into a court constituted by the state, with which . . . his dispute is." 72 Edmund Pendleton was also a supporter of the Constitution who apparently believed that the Constitution empowered individual citizens to sue the states. ${ }^{73}$

Surely this history supports, at least, a lack of consensus concerning the status of sovereign immunity when the Constitution was ratified. ${ }^{74}$ Indeed another piece of evidence that not all agreed

70 R. H. LEE, LetTers of A Federal FARMER (NuMrer III) (Oct. 10, 1787), reprinted in Pampencets on the Constitution of the Unted States 309 (P. Ford ed. 1888).

71 C. JACOBS, supra note 3 , at 34, 39. Evidence that their stated positions were disingenuous may be found in THE FEDERALIST No. 80 (A. Hamilton), discussed infra note 75 \& accompanying text; and in Marshall's statement, made some years later when he was Chief Justice, that article III did permit suits against states. Cohens v. Virginia, 19 U.S. ( 6 Wheat.) 264, 412 (1821) ("in its origin, the judicial power was extended to all cases arising under the Constitution or laws of the United States, without respect to parties").

72 T. CoXe, AN Examonation (NUMBer IV) 19 (1788), reprinted in PaMperlets on the Constrtutron of the UNTTEd States 149 (P. Ford ed. 1888). Coxe, a Pennsylvanian, was a member of the Continental Congress. The cited tract was among the first pro-ratification pamphlets to appear and reportedly was widely circulated. Id. 133.

73 Guthrie, The Eleventh Article of Amendment to the Constitution of the United States, 8 Colum. L. Rev. 183, 184 (1908). See also Pendleton's defense of the judiciary article, 3 Erriot's Debates, supra note 51, at 549.

74 The chronology of the Virginia Convention as well supports the view that the Madison-Marshall argument was made to counter the anti-federalists and, also, suggests that it did not necessarily prevail. Edmund Randolph first mentioned the issue of state suability at the Convention when he praised the Constitution for including it. Henry's and Mason's statements followed, detailing the dire consequences to the states that would follow from "forcing them to pay, shilling for 
with the Madison-Marshall-Hamilton pro-immunity statements comes from The Federalist 80, in which Hamilton himself, in the paper immediately preceding the much quoted one supporting immunity, indicates that states can be sued by private citizens and that this is to be applauded. ${ }^{75}$ And the influx of private suits against the states, commenced as soon as the national judiciary was

shilling". In fact there was a long discussion, joined in by others as well, on the Constitution's financial implications for state treasuries. It is at this point that Madison came up with the argument that states could not be sued, an argument that was answered by Henry, then reiterated by Marshall. Randolph concluded discussion of the subject at the Virginia Convention; his view apparently remained that the Constitution made states suable by individual citizens and that it was the better for this provision. See 3 Elurot's Debates, supra note 51 (record of Virginia ratification convention).

75 Hamilton speaks of "[t]he power of determining causes . . . between one State and the citizens of another" as "essential to the peace of the Union." TrEe Federaxist No. 80 (A. Hamilton) 501 (B. Wright ed. 1961) (1st ed. 1788). One could read this consistently with The Federalist No. 81, however, by saying only suits by states against individuals are contemplated. Hamilton also refers in The Federalist No. 80 to the need always to have "a constitutional method of giving efficacy to constitutional provisions. What, for instance, would avail restrictions on the authority of State legislatures, without some constitutional mode of enforcing the observance of them?" Id. 500. The prohibitions on the states he proceeds to list, however, are ones in which the plaintiff in an enforcement action would as likely be the United States as an individual citiren; "[ $t]$ he imposition of duties on imported articles, and the emission of paper money" were given as examples; violation of the contract clause was not.

Further on, however, The Federalist No. 80 more clearly envisions suits by individuals against states.

It may be esteemed the basis of the Union, that "the citizens of each State shall be entitled to all the privileges and immunities of citizens of the several States." And if it be a just principle that every government ought to possess the means of executing its own provisions by its authority, it will follow, that in order to the inviolable maintenance of that equality of privileges and immunities to which the citizens of the Union will be entitled, the national judiciary ought to preside in all cases in which one State or its citizens are opposed to another State or its citizens. To secure the full effect of so fundamental a provision against all evasion and subterfuge, it is necessary that its construction should be committed to that tribunal which, having no local attachments, will be likely to be impartial between the different States and their citizens, and which, owing its official existence to the Union, will never be likely to feel any bias inauspicious to the principles on which it is founded.

Id. 502 (emphasis in original). While Hamilton's statement is not absolutely explicit on the point, it almost certainly contemplates suit against the state by an individual. He does not suggest that the privileges and immunities of which he speaks can be raised only defensively. Moreover the privileges and immunities would not be secured for individual defendants if the state as plaintiff could choose to proceed in the state rather than the federal forum. (In fact, in the first Judiciary Act, federal and state courts were given concurrent jurisdiction over these cases, Judiciary Act of 1789 , ch. $20, \S 11,1$ Stat. 78 (current version at 28 U.S.C. $\$ 1332$ (1970)), and no provision was made for removal of these cases, id. \$12.) The Federalist No. 80 statement, therefore, rather clearly assumes that states are subject to suit by another state's citizens. 
established, ${ }^{76}$ is further evidence that it was not clear to all that the states' immunity persisted.

The Supreme Court's holding in Chisholm v. Georgia that states may be sued by citizens of other states was not therefore the clear contravention of a general understanding that it has long been said to be. ${ }^{77}$ Chisholm was, however, the first Supreme Court decision to be overturned by constitutional amendment: Chisholm was repudiated in the eleventh amendment, removing suits between a state and citizens of another state from the federal judicial power. ${ }^{78}$

\section{If Sovereign Immunity Survived, In What Form Did It Do So?- The Importance of Distinguishing Between Article III Imposition and Article III Neutrality}

In attempting to divine the significance of all this history today, it is instructive to observe that the debate traced above concerning the significance of article III to states' sovereign immunity reflects two basic positions. One (espoused by Randolph and Wilson, among others, and adopted by the Court in Chisholm) is that article III took away the states' immunity by granting federal court jurisdiction over suits to which states were parties; the other (advocated by Madison, Marshall, and the Hamilton of The Federalist 81 ) is that article III did not affect states' immunity but left it unimpaired. These two positions I will refer to as constitutional

76 I C. WArRen, supra note 2, at 91-93. The initial Supreme Court cases are Vanstophorst v. Maryland, 2 U.S. (2 Dall.) 401 (1791); Oswald v. New York, 2 U.S. (2 Dall.) 401 (1792); Indiana Co. v. Virginia (not reported; see 1 C. WARREN, supra note 2 , at 92 n.1.). For a detailed account of Vanstophorst and Oswald, as well as of Chisholm and other suits against states brought shortly after Chisholm, see Mathis, The Eleventh Amendment: Adoption and Interpretation, 2 GA. L. REv. 207, 215-30 (1968).

77 The two members of the Committee of Detail who were on record as believing that article III abrogated sovereign immunity played prominent roles in Chisholm. James Wilson wrote one of the majority opinions; Edmund Randolph represented the plaintiff. Randolph was also Attorney General of the United States at the time.

78 Historians are divided concerning the strength of the reaction to Chisholm $v$. Georgia. I C. WARREN, supra note 2, at 96-101; Nowak, supra note 3, at 1433-41. See also C. JACOBS, supra note 3, at 55-66. Clearly there was outrage at the decision, at least on the part of some. One newspaper writer blamed the result on "the 'craft and subtility of lawyers' [who] had introduced this clause into the Constitution as "the plan of all aristocrats to reduce the States to corporations." " Another claimed that the decision "involved more danger to the liberties of America than the claims of the British Parliament to tax us without our consent." I C. WARREN, supra note 2, at 97 (quoting contemporary newspapers). The Georgia House of Representatives responded to the decision by enacting a provision that anyone attempting to execute process in Chisholm will be "guilty of felony and shall suffer death, without benefit of clergy, by being hanged." Id. 100. 
abrogation of states' immunity and constitutional neutrality on the question. Article III is sometimes read today, however, to go beyond either of these positions; it is sometimes taken to impose sovereign immunity as a constitutional requirement. ${ }^{79}$

It is ironic that the same constitutional language-article III's language concerning the extent of the judicial power-should constitute the textual support both for the position that the Constitution requires immunity and for the position that the Constitution prohibits it. The position that article III imposes a constitutional requirement of immunity surely goes beyond anything argued in the constitutional debates. It has no historical support. Neither constitutional language nor constitutional intent provide any basis for it.

Hans $v$. Louisiana ${ }^{80}$ (the case initially holding that sovereign immunity extends to citizen suits) seemingly did not view the immunity as a constitutional requirement. That case is wholly consistent with the view that sovereign immunity survived article III as only a common law doctrine. The Court there did not speak of article III creating an immunity, though it forcefully contended that the article left preexisting sovereign immunity unimpaired. ${ }^{81}$ The position that article III imposes immunity has developed more recently. Seemingly it evolved simply by courts misreading the Madison, Marshall, and Hamilton arguments for constitutional neutrality, thus running together two very different positions. Mr. Justice Marshall's opinion in Government Employees, set out above, is typical.82 The finding (relying on Marshall, Madison

79 Employees of Dep't of Public Health and Welfare v. Department of Public Health and Welfare, 411 U.S. 279, 291 (1973) (Marshall, J., concurring) and cases cited in note 82 infra.

80134 U.S. 1 ( 1890 ).

81 The opinion describes the issue facing the Chisholm Court as whether article III's language created "a power to enable the individual citizens of one State . . . to sue another State of the Union in the federal courts," or whether instead "it was not the intention to create new and unheard of remedies, by subjecting sovereign States to actions at the suit of individuals, (which [Justice Iredell in Chisholm] ... conclusively showed was never done before,) but only, by proper legislation, to invest the federal courts with jurisdiction to hear and determine controversies and cases, between the parties designated, that were properly susceptible of litigation in courts." Id. 12. See also id. 15, 16, 18.

The only language in the Hans opinion that suggests sovereign immunity as a constitutional requirement is the statement that it is "inherent in the nature of sovereignty." Id. 13, quoting THE FEDERArIST No. 8. Read as a whole, however, the opinion indicates sovereign immunity survived article III but not as a constitutional requirement.

Hans v. Louisiana is consistent with a common law view of sovereign immunity in non-citizen suits as well. See notes 90-94 infra and accompanying text.

82 See text accompanying note 38 supra. For other examples, see Monaco v. Mississippi, 292 U.S. 313, 323-25, 329-30 (1934); Smith v. Reeves, 178 U.S. 436, 
and Hamilton) that the Constitution does not "provide a mechanism for making States unwilling defendants in federal court" is silently transformed into a prohibition, in the judicial power language, against hearing the suits at issue. Why article III is read to impose sovereign immunity rather than leave it unaffected is unexplained. Thus the article III language has come to be read to support a position quite foreign to any of the contemporary positions concerning its meaning.

In sum, the proper approach is to find in the historical sources contemporary with the ratification of the Constitution some support for a view that article III abrogated states' immunity and some support for a view that it did not-that instead it left sovereign immunity unaffected. In that case, sovereign immunity did survive the Constitution, but it survived as a common law requirement. Historical sources do not support the position that article III imposes a requirement of sovereign immunity. The view that article III abrogates immunity is discredited today. Rejection of that position is supportable either by focusing on the MadisonMarshall-Hamilton statements and saying that they, rather than contrary statements, embody the "constitutional intent"; or by saying that at any rate the reaction to Chisholm and the eleventh amendment show a repudiation of the abrogation position. By either route one arrives at a view that sovereign immunity survives article III but is not required by it. This position is consistent with the statements of Madison, Marshall and Hamilton that article III does not require the abrogation of sovereign immunity; they nowhere claim that article III required its imposition. Sovereign immunity survives the adoption of the Constitution, then, but it is subject to modification or even abandonment by processes short of constitutional amendment.

\section{The Effect of the Eleventh Amendment}

How does the eleventh amendment affect the status of sovereign immunity? 83

One possibility would be to hold that the intent of the amendment was solely to repudiate the theory that article III abrogated judicial immunity and to revert to the Madison-Marshall-Hamil-

449 (1900); Virginia Coupon Cases, 114 U.S. 269, 337-38 (1885) (dissenting opinion). Cf. Williams v. United States, 289 U.S. 553, 573-77 (1933) (immunity of United States constitutionally mandated, on analogy to state immunity thought to be conferred by article III and eleventh amendment).

83 See cases cited note 31 supra for the proposition that the amendment imposes immunity not only for cases within its terms but in citizen suits as well. 
ton view expressed in the ratification debates. Thus the amendment adds nothing to our interpretation of article III: sovereign immunity is not abrogated by the Constitution but neither is it constitutionally required; it survives as a "pre-existing right of the State governments," ${ }^{84}$ as a well-established doctrine of common law that "[i]t is inherent in the nature of sovereignty not to be amenable to the suit of an individual without its consent." 85

To say that not even the eleventh amendment imposes sovereign immunity as a constitutional requirement is a bit startling. No Justice of the Supreme Court takes this position. ${ }^{86}$ The Justice who is the greatest proponent of a common law status for sovereign immunity is Mr. Justice Brennan. He believes that sovereign immunity had only common law status after ratification of article III. ${ }^{87}$ But he has never questioned the established interpretation of the eleventh amendment as imposing a constitutional requirement of immunity for those cases within its literal terms (suits brought by "Citizens of another State, or by Citizens or Subjects of any Foreign State"). His most important difference with the Court, then, concerns whether a constitutional doctrine of immunity covers suits by a state's own citizens. If the eleventh amendment

84 The Federautst No. 81 (A. Hamilton).

85 Id. 511 (B. Wright ed. I96I) (emphasis deleted).

86 Indeed the only case support is Hans v. Louisiana, 134 U.S. 1 (1890). And even though I believe that Hans' language shows sovereign immunity is only a common law requirement, see test accompanying notes 90-94 infra, the case generally has not been so interpreted.

87 Justice Brennan believes that article III is not a jurisdictional bar to federal courts entertaining suits against the states; it is neutral on the subject of sovereign immunity, permitting "the nonconstitutional but ancient doctrine of sovereign immunity," Edelman v. Jordan, 415 U.S. 651, 687 (1974) (Brennan, J., dissenting), to survive, but not itself imposing the doctrine. See Employees of Dep't of Public Health and Welfare v. Department of Public Health and Welfare, 411 U.S. 279, 315-19 (1973) (Brennan, J., dissenting). Further, Justice Brennan believes that "at least insofar as the States granted Congress specifically enumerated powers," Edelman v. Jordan, 415 U.S. 651, 687 (1974), they surrendered their immunity when they ratified the Constitution. The eleventh amendment reimposed their immunity but only for the other suits explicitly mentioned in the amendment. It did not affect the common law status of the doctrine in citizen suits. Therefore when Congress, acting within its article I (or other) powers, subjects states to federal suit, its enactments, when applied to citizen suits, do not collide with any state right to immunity. See Employees of Dep't of Public Health and Welfare v. Department of Public Health and Welfare, 411 U.S. 279, 299-301, 309-10 (1973). See Parden v. Terminal Ry., 377 U.S. 184 (1964).

Justice Brennan has not discussed the effects of his view of sovereign immunity on judicial development of the immunity doctrines. The subject will be explored in the next article in this series. 
imposes a constitutional doctrine of immunity at all, it makes sense thus to limit it to its terms.88

But the amendment need not be read to impose immunity as a constitutional requirement. Sovereign immunity may be only a common law doctrine in noncitizen as well as citizen suits. It is perfectly possible for a constitutional amendment not to impose a constitutional requirement, but instead only to overturn a constitutional interpretation that the Supreme Court has rendered. The eleventh amendment on its face does not reveal whether the sovereign immunity doctrine has constitutional status. And reading the amendment only to restore sovereign immunity as a common law doctrine makes more sense than any of the alternatives, ${ }^{89}$ in view of the wording of the amendment and its historical context.

88 Despite the contrary reasoning in Hans $v$. Louisiana, see notes 32 \& 33 supra and accompanying text, it seems proper to accept the express limitations on the constitutional provision, even if those limitations seem irrational. Furthermore, there may have been reasons for distinguishing citizen and noncitizen suits, even if the eleventh amendment did impose a constitutional immunity requirement. Possibly the amendment's framers overlooked citizen suits (or even intentionally omitted them) because they did not then exist. Since Congress had not granted federal question jurisdiction to the federal courts, there was no jurisdictional basis upon which the suits could rest. Indeed, except for a one-year period starting in 1801, Judiciary Act of 1801, ch. 4, $\$ 11,2$ Stat. 92 (repealed by Judiciary Act of 1802, ch. $8, \S 1,2$ Stat. 132), Congress would not grant general federal question jurisdiction until 1875. Judiciary Act of $1875, \mathrm{ch} .137, \S 1,18$ Stat. 470 (current version at 28 U.S.C. $\$ 1331(1970)$ ). Starting in the $1860^{\prime}$ s, however, Congress did place a series of Civil Rights Acts within the federal jurisdiction. See Wrigrt \& Muruen, supra note 39 , at $\$ 3561 \mathrm{nn} .3$ \& $4 ; i d$. $\$ 3573$.

If this explanation is accepted, then when citizen suits were placed within the federal jurisdiction, sovereign immunity governed those cases only as a common law doctrine; even if the eleventh amendment's Framers would not have desired a different doctrine to prevail in citizen and noncitizen suits, they simply had not included citizen suits within their amendment. Hans v, Louisiana, 134 U.S. 1 (1890), which first held states immune from federal suit by their own citizens, is not inconsistent with this argument. See note 81 supra. It is only after Hans that the Court has unambiguously (and, I think, with Mr. Justice Brennan, incorrectly) claimed constitutional status for sovereign immunity in citizen suits. See cases cited note 4 supra.

If courts were to follow Justice Brennan's view that immunity is a constitutional requirement in noncitizen suits only, Congress could allow most claims against states to be prosecuted by altering the common law immunity doctrine governing suits by a state's own citizens. In impact, therefore, Justice Brennan's immunity doctrine would not differ drastically from this Article's proposal.

89 Recent commentary has proliferated the number of eleventh amendment interpretations. Under one view, sovereign immunity, though a constitutional requirement, only prohibits incursions by the federal judiciary and leaves Congress free to adjust the immunity to modern needs. Nowak, supra note 3; Tribe, Intergovernmental Immunities in Litigation, Taxation, and Regulation: Separation of Powers Issues in Controversies About Federalism, 89 Fanv. L. REv. 682, 683-99 (1976). This view, which resembles the Court majority's approach, will be analyzed further in my article on congressional power to abridge states' immunity. Another author argues that the eleventh amendment sustains state immunity against federal suit on state-created causes of action only. Cullison, supra note 2. Baker, Federalism and the Eleventh Amendment, 48 U. CoLo. L. REv. 139 (1977), suggests that 
There is nothing in the history of the eleventh amendment to cast doubt upon the interpretation set out above-that its sole effect was to allow sovereign immunity to survive article III as a common law requirement. The one thing that is clear about the amendment is that its purpose was to overturn Chisholm v. Georgia, as the suggested interpretation would most certainly do. The question is, however, just how broad this overturning was to be. The amendment passed without debate, and contemporary indications of the intended scope of the amendment are not available.

There is an argument from Hans $v$. Louisiana that supports a common law view of sovereign immunity even for cases unambiguously within the eleventh amendment. In Hans the Court said the purpose of the amendment was to write into law the Iredell dissent in Chisholm.90 That dissent clearly took the position that state sovereign immunity survived as a common law doctrine, not that the doctrine had constitutional force. Because Justice Iredell found that no statutes, before or after the Constitution, purported to alter common law doctrine, ${ }^{91}$ he saw the central issue as

whether, previous to the adoption of the constitution ... an action of the nature like this before the court could have been maintained ... upon the principles of the common law, which I have shown to be alone applicable. If it could, I think it is now maintainable here: If it could not, I think, as the law stands at present, it is not maintainable; whatever opinion may be entertained upon the construction

courts have continually departed from the constitutional language to vindicate prevailing principles of federalism. Finally, C. JACOBS, supra note 3 , at 162-63, like Justice Brennan, advocates restriction of the effect of the eleventh amendment to its explicit ban on noncitizen suits.

None of these takes the position herein advocated, that sovereign immunity is altogether a common law doctrine.

90 Hans v. Louisiana, 134 U.S. 1, 12, 14, 18-19 (1890). Justice Iredell, the only dissenter in Chisholm, had presided in the suit when Chisholm brought it against Georgia in the circuit court. There as well he had ruled that Georgia could not be sued. Mathis, The Eleventh Amendment: Adoption and Interpretation, 2 GA. L. REv. 207, 218 (1968).

91 Justice Iredell said the Court lacked jurisdiction because "there is no doubt, that neither in the state now in question, nor in any other in the Union, any particular legislative mode, authorizing a compulsory suit for the recovery of money against a state, was in being, either when the constitution was adopted, or at the time the judicial act was passed." Chisholm v. Georgia, 2 U.S. (2 Dall.) 419, 434 (1793) (Iredell, J., dissenting). He went on to say "it is certain, that in regard to any common-law principle which can influence the question before us, no alteration has been made by any statute, which could occasion the least material difference, or have any partial effect." Id. And further, "If, therefore, no new remedy be provided ... we have no other rule to govern us, but the principles of the preexistent laws, which must remain in force until superseded by others . . . ." Id. 436 . 
of the Constitution, as to the power of Congress to authorize such a one. ${ }^{22}$

After a long discussion of the common law principles of sovereign immunity, Justice Iredell concluded

[t] hat there are no principles of the old law, to which we must have recourse, that in any manner authorize the present suit, either by precedent or by analogy. The consequence of which, in my opinion, clearly is, that the suit in question cannot be maintained, nor, of course, the motion made upon it be complied with. ${ }^{93}$

At the end of his opinion, Justice Iredell again made clear that his position, finding immunity in the state, did not rest upon a constitutional basis:

So far as this great question affects the constitution itself, if the present afforded, consistently with the particular grounds of my opinion, a proper occasion for a decision upon it, I would not shrink from its discussion. But it is of extreme moment that no judge should rashly commit himself upon important questions, which it is unnecessary for him to decide. My opinion being, that even if the constitution would admit of the exercise of such a power, a new law is necessary for the purpose, since no part of the existing law applies, this alone is sufficient to justify my determination in the present case. ${ }^{94}$

92 Id.

93 Id. 449.

94 Id. Iredell then went on to state:

So much, however, has been said on the constitution, that it may not be improper to intimate that my present opinion is strongly against any construction of it, which will admit, under any circumstances, a compulsive suit against a state for the recovery of money. I think every word in the constitution may have its full effect without involving this consequence, and that nothing but express words, or an insurmountable implication (neither of which I consider, can be found in this case), would authorize the deduction of so high a power. This opinion I hold, however, with all the reserve proper for one, which, according to my sentiments in this case, may :be deemed in some measure extra-judicial. With regard to the policy of maintaining such suits, that is not for this court to consider, unless the point in all other respects was very doubtful. Policy might then be argued from with a view to preponderate the judgment. Upon the question before us, I have rio doubt. I have therefore nothing to do with the policy. But I confess, if I was at liberty to speak on that subject, my opinion on the policy of the case, would also differ from that of the attorney general. It is, however, a delicate topic. I pray to God, that if the attorney general's doctrine, as to the law, be established by the judgment of this court, all 
If the purpose of the eleventh amendment truly was to write Iredell's opinion into law, then its purpose was to allow sovereign immunity to survive as a common law requirement.

At first reading it may seem that the wording of the eleventh amendment is an obstacle to viewing the amendment as simply restoring immunity to its pre-Constitution position. The problem lies in the provision that the "[j] udicial power of the United States shall not be construed to extend to" the cases in question. Generally the United States' judicial power must "extend to" a class of cases for the federal judiciary to be able to hear those cases at all. Thus the "extend to" language of the amendment can be deemed to prohibit federal courts, as a constitutional matter, from entertaining the cases mentioned. This interpretation, however, has its own difficulties, because in some ways the cases are not deemed to be outside the United States' judicial power: it is well-established that federal courts may hear the suits upon 'the sovereign's consent. ${ }^{95}$ Jurisdiction of other cases outside the judicial power cannot be conferred upon federal courts by consent; ${ }^{96}$ in other contexts, the judicial power limitation is absolute.

The judicial power language can be interpreted to avoid this difficulty, and the interpretation that does so leaves sovereign immunity in a common-law status. The provision that the "[j]udicial power of the United States shall not be construed to extend to" certain classes of cases may mean simply that the language should not be deemed affirmatively to allow the prosecution of those cases, as it had been deemed to do in Chisholm. The eleventh amendment then would simply overturn Chisholm's abrogation of sovereign immunity. The cases the amendment enumerates would be outside the judicial power only in the sense that the judicial power language of article III does not compel that they be heard.

In addition to avoiding the anomaly of consent seemingly expanding the United States' judicial power, a common-law reading of sovereign immunity removes two other conceptual difficulties

the good he predicts from it may take place, and none of the evils with which, I have the concern to say, it appears to me to be pregnant.

Id. 449-50. The Court in Hans was not referring to this discussion, but to Iredell's development of his principal common law argument, when it adopted Iredell's views as its own. This is clear from Hans, in which Iredell's common law arguments are discussed extensively. See 134 U.S. at 12-19.

95 See cases cited note 8 supra.

96 Generally the rule is that the article III judicial power cannot be expanded by consent of the parties, Louisville \& Nashville R.R. v. Mottley, 211 U.S. 149 (1908), or by congressional legislation, Marbury v. Madison, 5 U.S. ( 1 Cranch) 137 (1803). 
with the conventional view that article III and the eleventh amendment impose a constitutional requirement of sovereign immunity. First, a similar rationale is provided for the sovereign immunity of the federal government and for state sovereign immunity in all the suits where it exists: the scope of federal immunity and of all types of state immunity is basically the same because they have the same source, the common law of sovereign immunity. ${ }^{97}$ Second, and most compelling, the omission of suits by a state's own citizens from the language of the eleventh amendment makes sense under this interpretation. Under the conventional view of the amendment, the omission seems irrational; indeed the Supreme Court has found it sufficiently irrational to forbid noncitizen suits while allowing citizen suits that it has operated as if the limitation did not exist. If, however, all the eleventh amendment does is say that article III should not be read affirmatively to authorize the suits with which the amendment deals, there is simply no need for a like provision for suits by a state's own citizens, because there is no language in article III that could be read affirmatively to authorize those suits. It is only if the result of the eleventh amendment is to forbid, as a constitutional matter, the suits it enumerates that one is hard pressed to find a rationale for so distinguishing between citizen and noncitizen suits.

A common law view of sovereign immunity thus fits better with the eleventh amendment's wording than does a constitutional view, although neither interpretation is absolutely trouble-free.

Since the eleventh amendment passed with so little discussion, it is not surprising that the Framers failed to differentiate be-

97 It is largely irrelevant to the scope of federal immunity whether it is a constitutional or a common law requirement. If it is common law, it can be changed by congressional action. Also, if it is constitutional, it can be changed by congressional action as long as the rule persists that jurisdiction attaches upon the sovereign's consent. (One case disagreed with the consent rule as applied to the United States, Williams v. United States, 289 U.S. 553 (1933), but Williams has not been followed in that regard. See, e.g., Glidden v. Zdanok, 370 U.S. 530, 562-66 (1962). Cf. Utah v. United States, 403 U.S. 9 (1971) (original action).) Whether federal immunity is of constitutional or common law stature could make a difference only if the judiciary were to take an active role in altering common law immunity, a more active role than courts would take as the interpreters of constitutional immunity. Since Congress speaks often concerning United States' immunity, a highly creative judicial role in developing federal common-law there may be unlikely.

With state immunity, the question of constitutional or common law status at least in theory would seem more significant. Congress, as well as state legislatures and judiciaries, could alter a common law immunity requirement. The consent exception to a constitutional rule of immunity, however, would refer to consent on the part of the state, not the federal government. My forthcoming article discussing court rulings on congressional power to abridge states' immunity will examine how much difference acceptance of a constitutional status for sovereign immunity has made in practice. 
tween repudiating Chisholm's abrogation of sovereign immunity and establishing that immunity as a constitutional requirement. 'The result of the positions was in many ways precisely the same: Chisholm and its reasoning were overturned, and sovereign immunity prevailed. The difference would develop only if efforts were made to modify sovereign immunity, by means short of constitutional amendment.98 If the desired result was simply an overturning of Chisholm, it is not surprising that contemporaries did not advert to differences between sovereign immunity as a constitutional and as a common law requirement.

A fuller discussion of the consequences of thus viewing sovereign immunity as a common law development will be undertaken in the next article in this series. Whether it would greatly change the law depends upon the Court's opinions delineating the bounds on sovereign immunity in application, which I will discuss there, and on how far those opinions depart from the practical consequences that would result from the common law model. For now, it suffices to point out that viewing sovereign immunity as a common law doctrine would effectuate the generally desirable result of leaving immunity as a question of policy, to be determined by Congress and adjusted to changing notions concerning the proper role of the doctrine. To some extent it would also affect courts' leeway in deciding sovereign immunity issues. ${ }^{99}$ Certainly sovereign immunity could, under the common law approach, have the same contours it has today, if Congress and the courts found its current limits to be desirable. In any event, making its nonconstitutional status explicit should help avoid the situation described in United States $v$. Lee, ${ }^{100}$ where the Court said the immunity doctrine had always been treated as established, without the reasons for it ever being given. Moreover, most commentators today are

98 If sovereign immunity were regarded simply as an established common law doctrine, Congress could modify it. The Congress that passed the eleventh amendment was not of a mind to do so, however. Also, in an era of freewheeling federal common law, the federal judiciary might itself make desired modifications. Undoubtedly Congress would have greeted such an effort with dismay if it followed closely upon the enactment of the amendment. But this does not in itself show that the eleventh amendment made the immunity doctrine a constitutional requirement. If Congress had considered the issue (as it probably did not), it might well have not feared such a step from the judiciary, a step that was not presaged by the very different reasoning of the Chisholm opinions.

99 There is evidence that in the past immunity has been handled as a policy question varying with the demands of the times. See generally Baker, supra note 89.

100106 U.S. 196, 207 (1882). The Court was speaking of both the states' and the United States immunity. 
sharply critical of sovereign immunity, ${ }^{101}$ and its persistence is often explained by the supposed constitutional compulsion behind the doctrine. ${ }^{102}$

\section{B. Does the Sovereign Immunity Protection Extend to State Courts?}

Viewing state immunity as non-constitutional also helps resolve another issue of eleventh amendment interpretation-whether the amendment's protection extends to state courts. Is the eleventh amendment of any relevance when states are sued in state court on federal causes of action? ${ }^{103}$

A reading of the amendment would suggest that the answer to this question is an obvious negative, since the amendment is limited in terms to a prohibition of a certain construction of the United States' judicial power. Because the language claimed to be relevant in article III similarly describes the extent of the federal judicial power, any sovereign immunity protection that article extends would seem also to reach only federal courts.

The issue arose recently when Mr. Justice Marshall, in his concurring opinion in Government Employees, ${ }^{104}$ made the obvious answer explicit. Justice Marshall took the position that a particular federal statute purported to lift the sovereign immunity protection

101 See, e.g., 3 K. Davis, Administrative Law Treatise, $551-72$ (1976). For judicial criticism, see, e:g., National City Bank v. Republic of China, 348 U.S. 356, 359 (1955) (Frankfurter, J.); Stone v. Arizona Highway Comm'n, 93 Ariz. 384, 381 P.2d 107 (1963); Muskopf v. Corning Hosp. Dist., 55 Cal. 2d 211, 359 P.2d 457, 11 Cal. Rptr. 89, modified sub nom. Corning Hosp. Dist. v. Superior Ct., 57 Cal. 2d 482, 370 P.2d 325, 20 Cal. Rptr. 620 (1961); Hargrove v. Cocoa Beach, 96 So. 2d 130 (Fla. 1957).

102 See C. JACOBS, supra note 3 , at 160 ("continued observance [of sovereign immunity] . . . should depend upon whether it is incorporated into the Constitution and hence made obligatory upon the judiciary unless waived by the government"); Comment, Private Suits Against States in the Federal Courts, 33 U. CFr. L. REv. 331, 332 (1966) (the major reason sovereign immunity retains any vitality today is the supposed constitutional basis for the doctrine).

Hart \& Wechsler ask whether "the Supreme Court in modern times has not tended actually to enlarge the scope of sovereign immunity, out of misapprehension of its historical foundations, while at the same time professing to regard it with disfavor as an anachronism which should be narrowly confined." P. BATor, P. Misekin, D. Shapiro \& $\mathrm{H}$. Wechsler, Hart \& Wechster's Tue Federal Courts and the Federal System 1339 (2d ed. 1973). The authors also made this statement in their first edition, prior to the Court's decision in Edelman v. Jordan, 415 U.S. 651 (1974), but that decision is in many ways a paradigm example of the authors' point.

${ }_{108}$ An analogous issue is whether a state, in its courts, may subject another state to liability. See Hall v. University of Nevada, 8 Cal. 3d 522, 503 P.2d 1363, 105 Cal. Rptr. 355 (1972), cert. denied, 414 U.S. 820 (1973). But see Western Union Telegraph Co. v. Pennsylvania, 368 U.S. 71, 80 (1961) (dictum).

104411 U.S. at 287 (Marshall, J., concurring). 
in order to allow state hospital or school employees to sue the states for overtime pay or for unpaid minimum wages. He found the statute unconstitutional, however, on the ground that Congress lacks power to lift a state's immunity from federal suit without the state's consent. ${ }^{105}$ Nonetheless, he pointed out, his position did not render unenforceable congressional statutes, in areas within Congress' article I powers, regulating states' primary conduct. ${ }^{106}$ Suits to enforce such statutes can be brought in state court, for Congress may validly lift any immunity the state has there. ${ }^{107}$ The Court majority said that arguably Congress could permit suit in state courts, but that it need not resolve the question. ${ }^{108}$

There are some indications that prior to Government Employees the assumption was that Congress could not impose these suits in state court. In Parden $v$. Terminal $R y .,^{109}$ for example, the Court seemed to accept, without questioning its propriety, Alabama's assertion that its courts would not hear the suit in question. ${ }^{110}$ Similarly in Hans v. Louisiana, ${ }^{111}$ the Court indicated that the result of its opinion, recognizing sovereign immunity in the federal courts even in citizen suits, was to leave to state legislatures the option whether to waive immunity or not. The Court did not contemplate imposition on the state judiciary by Congress. ${ }^{112}$

105 Id. 296-98.

108 This area appeared much larger at the time of Government Employees than it has since. In National League of Cities v. Usery, 426 U.S. 833 (1976), the Court cut back sharply on Congress' ability to regulate the states, invalidating the very enactments at issue in Government Employees. Both Usery and Government Employees are subjects of extensive further discussion in the next article.

107 Responding to Government Employees, Congress has since attempted explicitly to impose the suits in question upon state courts. Fair Labor Standards Amendments of 1974, Pub. L. No. 93-259, §6, 88 Stat. 55 (amending 29 U.S.C. $\$ 216(\mathrm{~b})$ (1970)). Earlier, Congress opened state courts to private damage suits against states under the Federal Employers' Liability Act $\$ 6,45$ U.S.C. 356 (1970).

108 The argument is that if we deny this direct federal court remedy, we in effect are recognizing that there is a right without any remedy. Section 16(b), however, authorizes employee suits in "any court of competent jurisdiction." Arguably, that permits suit in the Missouri courts but that is a question we need not reach. We are concerned only with the problem of this Act and the constitutional constraints on "the judicial power" of the United States.

411 U.S. at 287. In context it is clear that the only ground on which the Court considered questioning the state courts' jurisdiction concerned Congress' ability to impose suits upon the state.

109377 U.S. 184 (1964).

110 See 377 U.S. at 190 n.8.

111134 U.S. 1 (1890).

112 Id. 20-21. The Court also spoke of sovereign immunity as exempting the state from suit by individuals "in a court of justice," not limiting its holding to actions in federal courts. Id. 
The argument that Congress lacks power to impose suit upon the states, even in a state forum, is an argument that the Constitution confers upon the states an affirmative right of sovereign immunity. ${ }^{113}$ That the eleventh amendment's Framers adopted language of limitation of federal judicial power, the argument runs, reflects a belief on their part that the state judicial power in any event would not encompass such suits. They failed to mention the state judicial power either because they assumed that states could not be regulated under Congress' article I powers, or because they simply overlooked that Congress might adopt the expedient of subjecting a state to suit in its own courts.

A state case adopting this position is Mossman $v$. Donahey. ${ }^{114}$ Like Government Employees, it was a suit brought against state officials under the Fair Labor Standards Act. ${ }^{115}$ The court said:

If the Eleventh Amendment creates or affirms a substantive state right of sovereign immunity, as the [Supreme Court] has often stated, rather than a "hypertechnical" right for a state to choose a state forum, as Mr. Justice Marshall argues, then that right, to have any substantive effect, must be as applicable in a state forum as in a federal one. ${ }^{116}$

This position leaves something to be desired in terms of adherence to constitutional language. But, as previous discussion shows, that defect is shared by several established eleventh amendment positions; comporting with constitutional language has not proved a necessity in this area.

Another argument against the availability of state courts rests on their comparative inappropriateness as fora for these suits. If in any class of cases federal jurisdiction is to be preferred because

113 There is language in Supreme Court opinions that supports this view. E.g., Edelman v. Jordan, 415 U.S. 651, 673 (1974) (immunity as the state's "constitutional right"); Great Northern Life Ins. Co. v. Read, 322 U.S. 47, 51 (1944) ("A state's freedom from litigation was established as a constitutional right through the Eleventh Amendment."). For a critique of this approach, see Baker, Federalism and the Eleventh Amendment, 48 U. CoLo. L. Rev. 139, 163-65 (1977).

11446 Ohio St. 2d 1, 16, 346 N.E.2d 305, 314 (1976).

11529 U.S.C. $\$ \$ 201-19$ (1970).

11646 Ohio St. $2 \mathrm{~d}$ at 16, 346 N.E.2d at 314. But see Clover Bottom Hosp. \& School v. Townsend, 513 S.W.2d 505 (Tenn. 1974), another FLSA suit against the state in state court. There the court accepted Justice Marshall's view and held the state liable. Similarly the Second Circuit in Fitzpatrick v. Bitzer, 519 F.2d 559, $570-71$ (2d Cir. 1975), modified on other grounds, 427 U.S. 445 (1976), said Congress could impose damage suits against the states in state court, and it implied the same in McAuliffe v. Carlson, 520 F.2d 1305, 1309 (2d Cir. 1975), cert. denied, 427 U.S. 911 (1976). 
of possible bias in the state judiciary, suits against the state premised upon federal law would seem a prime category for federal jurisdiction. ${ }^{117} \mathrm{Mr}$. Justice Marshall's position-that these suits are viable only in the less appropriate fora-seems ironic, especially since the failure to extend to state courts the prohibition he finds on federal jurisdiction was probably an oversight. At most, however, this raises a question of policy for Congress when facing the issue whether to utilize state judiciaries-a question whether enforcement in the less appropriate fora is better than no enforcement at all. Justice Marshall is correct to conclude that nothing in the Constitution prevents Congress, within its article I and other powers, from thus making use of state judicial systems to resolve individuals' disputes with states.

Justice Marshall's position, obviously supported by the constitutional language, is, then, the sounder; here as well, the literal meaning of the eleventh amendment should prevail, and the sovereign immunity protection should not be construed to extend to state courts. There is no problem in following the literal meaning of the eleventh amendment in this respect if one adopts the earlier suggested view that the amendment's effect is limited to restoring sovereign immunity to the status of an established and permissible common law doctrine. It was only in the federal courts that the propriety of the doctrine had been challenged-by the argument that the judicial power language was intended to forbid it. Therefore it was only in the federal courts that the amendment needed to have any effect. The eleventh amendment does not confer upon the states a substantive right to enjoy sovereign immunity. Instead, common law controls, together, of course, with any supplementations Congress or state legislatures choose to make. Congress may impose suit upon states in state court, just as it may in federal court (despite Justice Marshall's views to the contrary), because the sovereign immunity doctrine has no constitutional sanction.

117 True, cases involving the state decided adverse to private plaintiffs claiming a federal right are appealable to the Supreme Court. Cohens v. Virginia, 19 U.S. (6 Wheat.) 264 (1821). Supreme Court review, however, is not an adequate substitute for original federal jurisdiction; when cases come to the Supreme Court, factual findings have already been made, and the case generally has already been shaped by the time review is sought. Osborn v. Bank of the United States, 22 U.S. (9 Wheat.) 738, 822-23 (1824) ("the insecure remedy of an appeal, upon [a] point, after it has received that shape which may be given to it by another tribunal"). See generally Field, Abstention in Constitutional Gases: The Scope of the Pullman Abstention Doctrine, 122 U. PA. L. REv. 1071, 1083-84 (1974); Mishkin, The Federal "Question" in the District Courts, 53 Colom. L. REv. 157, 158 n.9, 171-76 (1953). 